\title{
Analisis Kepuasan Mahasiswa FKIP Atas Kualitas Layanan Akademik Di Pusat Pelayanan Terpadu Universitas PGRI Palembang
}

\author{
Ermini ${ }^{1}$, Dina Sri Nindiati ${ }^{2}$, Muhammad Kurniawan ${ }^{3}$ \\ ${ }^{1}$ FKIP Universitas PGRI Palembang, ermini@univpgri-palembang.ac.id \\ ${ }^{2}$ FKIP Universitas PGRI Palembang, dinamrsyd@gmail.com \\ ${ }^{3}$ Fakultas Ekonomi dan Bisnis Universitas PGRI Palembang, iwanusman220516@gmail.com
}

\begin{abstract}
ABSTRAK
Penelitian ini bertujuan untuk (1) mengetahui apakah Kepuasan Mahasiswa FKIP atas Kualitas Layanan Akademik di Pusat Pelayanan Mahasiswa Universitas PGRI Palembang telah terpenuhi dan sesuai harapan mahasiswa, (2) untuk mengetahui instrument kualitas layanan (tangibles, reliability, responsiveness, assurance, dan empathy) mana yang memberikan kepuasan kepada mahasiswa FKIP Universitas PGRI Palembang tahun 2019-2020. Metode yang digunakan dalam penelitian ini adalah metode deskriptif untuk menggambarkan hubungan antar variabel melalui pengujian hipotesis. Penelitian ini menggunakan kuesioner sebagai alat pengumpulan data yang didistribusikan kepada 98 responden dari mahasiswa FKIP yang terpilih sebagai responden pada tahun akademik 2019-2020, dimana ada 7 item pertanyaanuntuk variable kualitas layanan dan 8 item pertanyaan untuk variable kepuasan mahasiswa. Berdasarkan hasil penelitian yang dilakukan, terdapat pengaruh yang signifikan secara simultan antara variabel kualitas layanan akademik $(X)$ terhadap variabel kepuasan mahasiswa $(\mathrm{Y})$. Ini dibuktikan dengan memperoleh dengan perolehan perhitungan lebih besar dari $t$ tabel $(5.207>1,660)$ dan koefisien 0,000 dan nilainya positif.
\end{abstract}

Kata kunci: Kepuasan Mahsiswa, Kulaitas Layanan Akdemik

\begin{abstract}
This study aims to (1) find out whether FKIP Student Satisfaction on the Quality of Academic Services at the Student Service Center of PGRI Palembang University has been fulfilled and according to student expectations, (2) to determine service quality instruments (tangibles, reliability, responsiveness, assurance, and empathy) which one gives satisfaction to FKIP students at PGRI Palembang University in 2019-2020. The method used in this study is a descriptive method to describe the relationship between variables through hypothesis testing. This study used a questionnaire as a data collection tool which was distributed to 98 respondents from FKIP students who were selected as respondents in the 2019-2020 academic year, where there were 7 question items for the service quality variable and 8 question items for the student satisfaction variable. Based on the results of the research conducted, there is a simultaneous significant effect between the academic service quality variable $(X)$ on the student satisfaction variable $(Y)$. This is evidenced by obtaining a calculation greater than t table $(5.207>1.660)$ and a coefficient of 0.000 and the value is positive.
\end{abstract}

Keywords: Student Satisfaction, Academic Service Quality

\section{A. PENDAHULUAN}

Pendidikan adalah usah asadar dan terencana untuk mewujudkan suasana belajar dan proses pembelajaran agar peserta didik secara aktif mengembangkan potensi dirinya untuk memiliki kekuatan spiritiual keagamaan, pengendalian diri, kepribadian, kecerdasan, akhlak mulia, serta keterampilan yang diperlukan dirinya, masyarakat, bangsa dan Negara, hal ini termaktub dalam UU No. 20 Tahun 2003 tentang Sistem Pendidikan Nasional.

Keadaan ini menyebabkan lembaga pendidikan harus memperhatikan kualitas pendidikan dan kelembagaan sehingga mampu serta unggul dalam persaingan tersebut. Salah satu yang perlu diperhatikan untuk meningkatkan kualitas perguruan 
tinggi adalah kualitas layanan terutama Kualitas Layanan Akademik terhadap mahasiswa.

Menurut Lewis \& Booms dalam Tjiptono \& Chandra (2014:180), kualitas layanan sebagai ukuran seberapa bagus tingkat layanan yang diberikan mampu terwujud sesuai harapan pelanggan. Sama seperti yang telah diungkapkan oleh Tjiptono (2014:157), kualitas layanan itu sendiri ditentukan oleh kemampuan perusahaan dalam memenuhi kebutuhan dan keinginan pelanggan sesuai dengan ekspektasi pelanggan.

Kualitas Layanan Akademik sangat penting karena akan membuat mahasiswa loyal kepada institusi, mahasiswa bersedia mempromosikan institusi tersebut kepada orang lain, meningkatkan animo masyarakat untuk melanjutkan pendidikan di institusi tersebut, meningkatkan bargaining position dariinstitusi, dan meningkatkan citra darii nstitusi tersebut.

\section{B. KAJIAN TEORI}

\section{1) Kepuasan Mahasiswa}

Menurut Tjiptono (2014) kepuasan atau ketidakpuasan pelanggan adalah respon pelanggan terhadap evaluasi ketidakpuasan (disconfirmation) yang dirasakan antara harapan sebelumnya atau harapan kinerja lainnya dan kinerja actual produk yang dirasakan setelah memakainya.

Perkembangan selanjutnya menurut Gilmore dalam Fandy Tjiptono (2014:17) layanan dapat dibedakan menjadi service sebagai aktivitas dan service sebagai konsep. Sebagai aktivita layanan mencakup kepuasan pelanggan, dalam hal ini jasa dipandang sebagai fungsi tambahan yang melengkapi produk fisik maupun non fisik. Layanan dijadikan keunggulan kompetitif, seperti keramahan dan kesigapan pegawai dalam menangani pelanggan. Sebagai konsep, layanan dapat berwujud organisasi yang meliputi struktur organisasi (bisnis maupun nirlaba yang berkecimpung di bidang jasa), produk inti (perluasan produk atau setiap aktivitas tambahan yang dirancang untuk memfasilitasi penyampaian produk inti), product support (setiap aktivitas yang berorientasi pada pelanggan yang berlangsung setelah produk inti disampaikan kepada pelanggan), dan Tindakan membantu dan memberikan saran kepada pelanggan. Dengan demikian pada hakikatnya setiap bisnis adalah bisinis jasa/layanan.

Selanjutnya, Sugito dikutip Rahayu (2013:4) mendefinisikan kepuasan mahasiswa sebegai berikut : Suatu keadaan dimana terpenuhinya keinginan, harapan, dan kebutuhan mahasiswa. Jika pelayanan yang diberikan dapat memenuhi keinginan, harapan, dan kebutuhan mahasiswa, maka dapat dinilai pelayanan itu memuaskan, dan sebaliknya, jika pelayanan yang diberikan tidak dapat memenuhi keinginan, harapan, dan kebutuhan mahasiswa, maka dapat disimpulkan pelayanan itu tidak memuaskan. Maka berdasarkan definisi tersebut, dapat disimpulkan bahwa kepuasan mahasiswa merupakan penilaian yang diberikan atas perbedaan antara harapan mahasiswa dengan kinerja atau hasil (kenyataan) yang dirasakan oleh mahasiswa atas pelayanan yang diberikan oleh fakultas.

Berdasarkan uraian di atas, dapat disimpulkan bahwa kepuasan mahasiswa merupakan suatu tanggapan mahasiswa yang terkait dengan pemenuhan suatu kebutuhan, termasuk pemenuhan kebutuhan yang tidak sesuai harapan atau pemenuhan yang melebihi harapan pelanggan (mahasiswa). Kepuasan mahasiswa akan tercapai apabila ada kesesuaian antara layanan akademik yang diberikan kepada mahasiswa dengan harapan mahasiswa. 


\section{2) Faktor Yang Mempengaruhi Kepuasan dan Harapan Mahasiswa}

Faktor-faktor yang menentukan harapan pelanggan meliputi kebutuhan pribadi, pengalaman masa lampau, rekomendasi dari mulut ke mulut, dan iklan (FandyTjiptono, 2014). Kepuasan terhadap layanan diwujudkan oleh faktor-faktor sebagai berikut:

a. Komunikasi dari mulut kemulut, Informasi yang diperoleh dari masyarakat yang memperoleh pelayanan yang memuaskan ataupun tidak, akan menjadi informasi yang dapat digunakan sebagai referensi untuk menggunakan atau memilih jasa pelayanan.

b. Kebutuhan pribadi, masyarakat selalu membutuhkan pelayanan yang tersedia sebagai kebutuhan pribadi yang tersedia pada waktu dan tempat sesuai dengan kebutuhan.

c. Pengalaman masa lalu, masyarakat yang pernah mendapatkan pelayanan yang memuaskan akan Kembali untuk memperoleh layanan yang memuaskan sesuai dengan kebutuhannya berdasarkan pengalamannya.

d. Komunikasi eksternal, sosialisasi yang luas dari sistem pelayanan mengenai fasilitas, sumberdaya manusia, serta kelebihan-kelebihan yang dimiliki suatu institusi akan mempengaruhi pemakaian jasa pelayanan oleh masyarakat.

Mahasiswa dapat mengalami salah satu dari tingkat kepuasan yang umum yaitu:

$>$ Jika kinerja di bawah harapan, mahasiswa akan tidak puas.

$>$ Kalau kinerja sesuai dengan harapan, mahasiswa akan puas.

> Apabila kinerja melampaui harapan, mahasiswa akan merasa sangat puas, senang, atau bahagia.

Untuk meningkatkan kepuasan konsumen (mahasiswa), maka dibutuhkan startegi, hal ini selaras dengan pendapat Tjiptono dikutip Maheswari (2013:2) yang menyatakan bahwa ada beberapa strategi yang dapat dipadukan untuk meraih dan meningkatkan kepuasan konsumen, yaitu sebagai berikut.

1) Relationship marketing, hubungan transaksi antara penyedia jasa dan pelanggan berkelanjutan, tidak berakhir setelah penjualan selesai. Dengan kata lain dijalin suatu kemitraan jangka Panjang dengan pelanggan secara terus menerus, sehingga dapat terjadi bisnis ulangan.

2) Superior customer service, berusaha menawarkan pelayanan yang lebih unggul daripada pesaingnya.

3) Uncondition alguarantees, komitmen memberikan kepuasan kepada pelanggan yang pada gilirannya akan menjadi sumber dinamisme penyempurnaan kualitas jasa dan kinerja perusahaan.

4) Penanganan keluhan yang efektif, penanganan keluhan yang baik memberikan peluang untuk mengubah seorang pelanggan yang tidak puas menjadi pelanggan yang puas bahkan menjadi pelanggan abadi.

5) Peningkatan kinerja perusahaan, strategi melakukan pemantauan dan pengukuran kepuasan secara berkesinambungan, sistem penilaian kinerja, penghargaan dan promosi karyawan didasarkan pada kontribusi mereka, memberdayakan karyawan sehingga mereka dapat mengambi Ikeputusan tertentu yang berkaitan dengan tugasnya.

6) Quality function deployment, praktek untuk merancang suatu proses sebagai tanggapan terhadap kebutuhan konsumen. 
Pengukuran kepuasan pelanggan menurut Kotler \& Keller yang dikutip Fandy Tjiptono (2014:369) paling tidak ada empat metode, antara lain:

a. Sistem keluhan dan saran. Misalnya menyediakan kotak saran dan keluhan, kartu komentar, customer hot lines, mempekerjakan petugas pengumpul pendapat atau keluhan pelanggan, dan lain-lain.

b. Ghost shopping (Mystery shopping) Perusahaan/lembaga menggunakan ghost shopping untuk mengamati kekuatan dan kelemahan produk serta pelayanan perusahaan dan pesaing.

c. Lost Customer Analysis, Perusahaan akan menghubungi para pelanggannya atau setidaknya mencari tahu pelanggannya yang telah berhenti membeli produk atau yang telah pindah.

d. Survai kepuasan. Survai biasanya dilakukan dengan kuesioner (dikirim lewat pos atau dibagikan pada saat pelanggan berbelanja), lewat telepon, e-mail, faks atau dengan wawancara langsung.

e. Sales-related methods. Kepuasan pelanggan diukur dengan kriteria pertumbuhan penjualan, pangsa pasar dan rasio pembelian ulang.

f. Customer panels. Perusahaan membentuk panel pelanggan yang nantinya dijadikan sampel secara berkala untuk mengetahui apa yang mereka rasakan dari perusahaan dan semua pelayanan perusahaan.

Beragamnya cara mengukur kepuasan pelanggan tersebut masih menunjukkan adanya kesamaan dalam enam konsep inti mengenai obyek pengukuran, menurut Tjiptono dikutip Tuerah, dkk (2015:425) menyatakan bahwa indikator kepuasan mahasiswa yaitu sebagai berikut:

1. Kepuasan pelanggan keseluruhan (Overaal Customer Satisfaction) Pelanggan langsung ditanya seberapa puas dengan produk atau jasa. Kepuasan diukur berdasar produk atau jasa perusahaan bersangkutan dan membandingkan dengan tingkat kepuasan keseluruhan terhadap produk atau jasa pesaing.

2. Dimensi kepuasan pelanggan, dilakukan melaluii dentifikasi kunci kepuasan pelanggan, penilaian spesifik produk dan layanan oleh pelanggan, meminta pelanggan membandingkan produk sejenis perusahaan dengan produk pesaing, dan meminta pelanggan menentukan dimensi yang paling penting bagi kepuasan pelanggan secara keseluruhan.

3. Kesesuaian harapan merupakan tingkat kesesuaian antara kinerja produk yang diharapkan oleh konsumen dengan yang dirasakan oleh konsumen

4. Niat beliulang (Repurchase Intention) merupakan kesediaan konsumen untuk berkunjung Kembali atau melakukan pembelian ulang terhadap produk terkait. Berhubung penelitian ini di Lembaga pendidikan yang merupakan tempat di mana mahasiswa sebagai pelanggan setiap harinya dating ke fakultas.

5. Kesediaan merekomendasikan (Willingness to Recomended) merupakan kesediaan konsumen untuk merekomendasikan produk yang telah dirasakannya kepada teman atau keluarga.

6. Ketidakpuasan Pelanggan (Costumer Dissatisfaction), jaminan kepuasan pelanggan berupa komplain, return atau pengembalian produk, biaya garansi, product recall, gethoktular negatif, dan defections (pelanggan beralih kepesaing).

\section{METODE PENELITIAN}

Metode yang digunakan dalam penelitian ini adalah metode deskriptif dengan menggunakan pendekatan kuantitatif. Metode penelitian deskriptif adalah suatu metode penelitian yang dimaksudkan untuk menggambarkan keadaan saat 
penelitian. Metode ini bertujuan untuk mengungkapkan fakta hubungan antara fenomena yang diteliti melalui pendeskripsian, pengembangan secara sistematis faktual dan akurat. Pendekatan kuantitatif adalah pendekatan penelitian dengan data penelitiannya berupa angka-angka, dan analisisnya menggunakan statistik (Sugiyono,2017:7).

\section{Lokasi Penelitian}

Penelitian ini dilaksanakan di Universitas PGRI Palembang yang terletak di Jalan Ahmad Yani Lr. Gotong Royong 9/10 Ulu Palembang. Universitas PGRI Palembang merupakan salah satu perguruan tinggi swasta yang dikota Palembang yang bergerak dibidang pendidikan baik strata 1 maupun strata 2 dan memiliki 5(lima) fakultas dan 1 pascasarjana. Dan salah satu fakultas yang ada di Universitas PGRI Palembang adalah Fakultas Keguruan dan IImu Pendidikan (FKIP).

\section{Sampel Penelitian}

Teknik pengambilan sampling dalam penelitian ini adalah dengan metode Purposive Sampling. Artinya responden (subjek) yang dipilih secara sengaja dengan karakteristik tertentu yang diyakini representative terhadap populasi penelitian. Untuk jumlah sampel di ambil dengan rumus Taro Yamane dikutip Riduwan (2010:65) sebagai berikut:

$$
n=\frac{N}{N \cdot d^{2}+1}
$$

\section{Keterangan :}

$$
\begin{array}{ll}
\mathrm{n} & =\text { Jumlah Sampel } \\
\mathrm{N} & =\text { Jumlah Populasi } \\
\mathrm{d}^{2} & =\text { Presisi yang ditetapkan sebesar 0,1 }
\end{array}
$$

Berdasarkan populasi diketahui sebesar1.420 mahasiswa. Jadi besarnya sampel yang digunakan adalah:

$$
\boldsymbol{n}=\frac{1.420}{(1.420) \cdot(0,1)^{2}+1} \quad \boldsymbol{n}=\frac{1.420}{(1.420) \cdot(0,01)+1}=98
$$

Berdasarkan hasil perhitungan sampel di atas, maka diperoleh sampel penelitian ini adalah 98 mahasiswa Fakultas Keguruan dan IImu Pendidikan Universitas Palembang Tahun Akademik 2019/2020.

\section{Variabel Penelitian}

Variabel penelitian adalah suatu variabel yang berdasarkan sustu sifat-sifat yang dapat diamati yang terdiri dari variabel bebas (independent) dan variabel terikat (dependent). Di mana variabel bebas merupakan variabel yang mempengaruhi variabel terikat, sedangkan variabel terikat merupakan variabel yang dipengaruhi oleh variabel bebas.

Dalam penelitian ini terdapat 2 (dua) variabel yaitu variabel bebas (independent) dan variabel terikat (dependent). Variabel bebas dalam penelitian ini adalah Kualitas Layanan Akademik. Kualitas Layanan Akademik merupakan suatu nilai yang diberikan oleh petugas untuk memberikan pelayanan yang diberikan sesuai dengan harapan pelanggan. Sedangkan variable terikatnya adalah Kepuasan Mahasiswa merupakan suatu tanggapan mahasiswa yang terkait dengan pemenuhan suatu kebutuhan, termasuk pemenuhan kebutuhan yang tidak sesuai harapan atau pemenuhan yang melebihi harapan pelanggan (mahasiswa). 


\section{$>$ Kualitas Layanan Akademik}

Kualitas Layanan Akademik merupakan suatu nilai yang diberikan oleh petugas untuk memberikan pelayanan yang diberikan sesuai dengan harapan pelanggan. Fungsi layanan atau pelayanan secara umum adalah untuk memudahkan orang lain, konsumen, atau siapa saja yang membutuhkan dalam memperoleh informasi, data atau dokumen lain.

\section{$>$ Kepuasan Mahasiswa}

Kepuasan mahasiswa merupakan suatu tanggapan mahasiswa yang terkait dengan pemenuhan suatu kebutuhan, termasuk pemenuhan kebutuhan yang tidak sesuai harapan atau pemenuhan yang melebihi harapan pelanggan (mahasiswa). Kepuasan mahasiswa akan tercapai apabila ada kesesuaian antara layanan akademik yang diberikan kepada mahasiswa dengan harapan mahasiswa.

\section{Defenisi Operasional}

Definisi operasional sering dijelaskan sebagai suatu spesifikasi kegiatan penelitian dalam mengukur variabel. Definisi operasional dari penelitian ini adalah sebagai berikut :

\section{$>\quad$ Variabel Terikat (Kepuasan Mahasiswa (Y))}

Variabel terikat (dependent variabel) adalah suatu variabel yang dikenai pengaruh (diterangkan) oleh variabel lain dan dalam notasinya ditulis dengan Y. Variabel terkait dalam penelitian ini adalah Kepuasan Mahasiwa FKIP Universitas PGRI Palembang. Menurut Tjiptono (2014:24) kepuasan atau ketidakpuasan pelanggan adalah respon pelanggan terhadap evaluasi ketidakpuasan (disconfirmation) yang dirasakan antara harapan sebelumnya atau harapan kualitas pelayanan lainnya yang dirasakan setelah memakainya. Dalam penelitian ini kepuasan mahasiswa diukur dari jawaban terhadap kuesioner dari mahasiswa FKIP Universitas PGRI Palembang yang terpilih sebagai sampel, dimana butir-butir pertanyaan disesuaikan dengan indikator yang diturunkan dari pengukuran kepuasan mahasiswa.

\section{$>\quad$ Variabel Bebas (Kualitas Pelayanan (X))}

Kualitas layanan akademik merupakan upaya sistematis dalam lembaga perguruan tinggi untuk memfasilitasi mahasiswa melalui proses pembelajaran sehingga mereka mampu mencapai kompetensi standar yang diterapkan. Kualitas layanan akademik dapat diukur dengan indikator-indikator yang meliputi: 1) Tangible (bukti langsung) 2) Reliability (reliabilitas) 3) Responsiveness (daya tanggap) 4) Assurance (jaminan) 5) Emphaty (empati).

Dalam penelitian ini kualitas pelayanan diukur dari jawaban terhadap kuesioner dari mahasiswa FKIP Universitas PGRI Palembang yang terpilih sebagai sampel, dimana butir-butir pertanyaan disesuaikan dengan indikator yang diturunkan dari pengukuran kepuasan mahasiswa. Sebagaimana yang terdapat pada tabel ini.

TABEL VARIABEL, INDIKATOR DAN KUESIONER KUALITAS LAYANAN AKADEMIK

\begin{tabular}{|c|c|c|c|}
\hline Variabel & Sub Variabel & Indikator & Item Pertanyaan \\
\hline $\begin{array}{l}\text { Kualitas } \\
\text { Layanan } \\
\text { Akademik } \\
(\mathrm{X})\end{array}$ & $\begin{array}{l}\text { Kehandalan } \\
\text { (Realibility) }\end{array}$ & $\begin{array}{l}\text { 1. Kehandalan layanan } \\
\text { yang diberikan } \\
\text { petugas } \\
\text { 2. Ketepatan waktu } \\
\text { yang disediakan }\end{array}$ & $\begin{array}{l}\text { 1. Kehandalan layanan yang } \\
\text { diberikan petugas ketika } \\
\text { mahasiswa mengalami } \\
\text { masalah akademik } \\
\text { 2. Ketepatan waktu dalam } \\
\text { menyelesaikan masalah }\end{array}$ \\
\hline
\end{tabular}




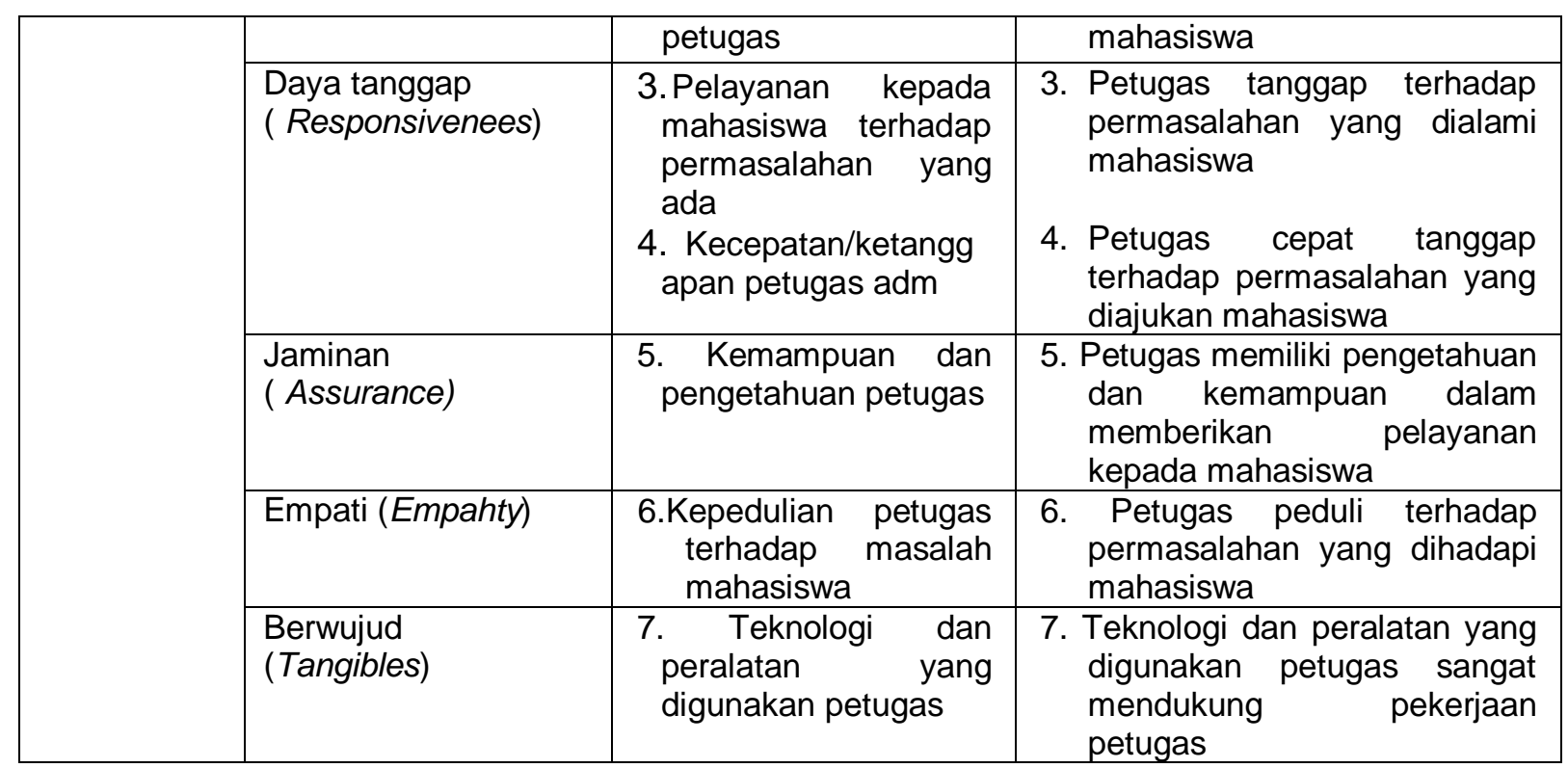

\section{Teknik Pengumpulan data}

Teknik pengumpulan data adalah teknik atau cara-cara yang dapat digunakan peneliti untuk mengumpulkan data. Pengumpulan data dilakukan untuk memperoleh informasi yang dibutuhkan dalam rangka mencapai tujuan penelitian. Metode pengumpulan data dalam penelitian ini dilakukan dengan menggunakan kuesioner. Atau kuesioner dapat juga diartikan sebagai daftar pertanyaan atau pernyataan yang harus diisi oleh responden, yang biasanya berupa angket.

Dari pendapat diatas Kuesioner yaitu metode pengumpulan data yang diperoleh dari jawaban yang diberikan responden berdasarkan daftar pertanyaan atau pernyataan yang telah disusun sebelumnya. Pertanyaan atau Pernyataan pernyataan dalam kuesioner dibuat nilai 1 sampai 5 untuk mewakili pendapat responden yang dimulai dari sangat tidak setuju sampai sangat setuju. Tujuan penyebaran angket adalah mencari informasiyang lengkap mengenai suatu masalah dari responden tanpa merasakhawatir bila responden memberikan jawaban yang tidak sesuai dengankenyataan dalam pengisian daftar pertanyaan.

\section{Instrumen Penelitian}

Instrumen yang akan dipergunakan dalam penelitian ini berupa angket. Penyebaran angket dalam penelitian ini berupa angket kepuasan mahasiswa atas Kualitas Layanan Akademik dengan menggunakan skala Likets dengan menggunakan ukuran interval, dimana menurut Menurut Sugiyono (2017:93) yang dimaksud dengan Skala Likert adalah sebagai berikut: "Skala Likert digunakan untuk mengukur sikap, pendapat, dan persepsi seseorang atau sekelompok orang tentang fenomena nasosial. Dalam penelitian, fenomena nasosial ini telah ditetapkan secara spesifik oleh peneliti, yang selanjutnya disebut sebagai variable penelitian.

\section{a) Uji Validitas}

Menurut Sugiyono, (2017:267), validitas merupakan derajat ketepatan antara data yang terjadi pada obyek penelitian dengan data yang dapat dilaporkan oleh peneliti. Uji validitas digunakan untuk mengukur sah atau valid tidaknya suatu instrumen. Suatu instrument dikatakan valid jika pertanyaan pada instrument mampu untuk mengungkapkan sesuatu yang akan diukur oleh instrument tersebut. 
Uji validitas dilakukan dengan bantuan SPSS. Untuk mengetahui pertanyaan mana yang benar-benar valid adalah dengan melihat nilai sig ( 2 tailed) dari masingmsing pertanyaan. Nilai sig (2 tailed) yang lebih kecil atau sama dengan $\alpha=5 \%$ (tingkat kepercayaan $95 \%$ ) adalah pertanyaan yang valid dan bisa digunakan untuk penelitian selanjutnya. Sedangkan pertanyaan dengan sig ( 2 tailed) lebih besar dari nilai $\alpha$ akan dibuang atau tidak digunakan untuk penelitian selanjutnya.

\section{b) Uji Reliabilitas}

Menurut Sugiyono (2017:268), reliabilitas berkenaan dengan derajat konsistensi dan stabilitas data atau temuan. Reliabilitas adalah indeks yang menunjukkan sejauh mana suatu alat pengukur dapat dipercaya atau dapat diandalkan. Bila suatu alat pengukur dipakai dua kali untuk mengukur gejala 56 yang sama dan hasil pengukuran yang diperoleh relative konsisten, maka alat pengukur tersebut reliabel. Dengan kata lain, reliabilitas menunjukkan konsistensi suatu alat pengukur dalam mengukur gejala yang sama.

Suatu intrumen penelitian dikatakan mempunyai nilai reliabitas yang tinggi apabila tes yang dilakukan mempunyai hasil yang konsisten dalam mengukur yang hendak diukur. Ini berarti semakin reliable suatu tes memiliki persyaratan, maka semakin yakin kita dapat menyatakan bahwa dalam hasil suatu tes mempunyai hasil yang sama ketika dilakukan tes kembali.

Data primer yang didapat dan diolah dengan menggunakan bantuan program statistik SPSS. Data dinyatakan reliabel apabila nilai pengujian lebih besar dari 0,5 atau $\alpha>0,5$.

\section{Teknik Analisis Data}

Teknik analisis adalah perangkat statistika deskriptif yang digunakan sebagai alat bantu bagi penelitiuntuk mengambil kesimpulan atas sejumlah data penelitian yang telah terkumpul. Penggunaan deskriftif disesuaikan dengan tujuan penelitian dan hasil yang diharapkan. Analisis deskriptif tentang kepuasan mahasiswa atas Kualitas Layanan Akademik, kemudian dianalisis secara deskriptif dengan menggunakan program SPSS. Hal ini, bertujuan untuk memperoleh gambaran mengenai kepuasan mahasiswa atas Kualitas Layanan Akademik.

\section{a) Analisis Regresi Linear Sederhana}

Metode analisis regresi digunakan untuk mengetahui hubungan sekaligus pengaruh dua variabel, di mana harus ditentukan variabel mana yang mempengaruhi variabel yang lain. Variabel yang mempengaruhi disebut variabel bebas (independent variable) biasanya digunakan simbol $X$, sedangkan variabel yang dipengaruhi disebut variabel terikat (dependent variable) biasanya digunakan simbol Y.

Persamaan regresi yang diuji adalah model regresi linier sederhana sebagai berikut:

\section{$\mathbf{Y}=\mathbf{a}+\mathbf{b X}$}

Keterangan :

$\mathrm{Y}=$ Kepuasan Mahasiswa

$\mathrm{X}=$ Kualitas Layanan Akademik

$\mathrm{a}=$ Nilai konstanta

$\mathrm{b}=$ Koefisien regresi 


\section{b) Uji Parsial (Uji-t)}

Uji-t untuk melihat seberapa besar pengaruh satu variabel bebas terhadap variabel terikat dengan asumsi variabel lainnya konstan bisa diterima (signifikan). Pengujian ini menggunakan tingkat signifikan $5 \%$ dan melakukan perbandingan antara thitung dengan $\mathrm{t}$ tabel.

Uji hipotesis yang digunakan dalam penelitian ini adalah:

Ho : b1 = 0 Artinya :

- Variabel bebas tidak dapat menerangkan variabel tidak bebas

$\mathrm{Ha}: \mathrm{b} 1 \neq 0$ Artinya:

- Tidak ada pengaruh diantara dua variabel yang diuji

- Variabel bebas dapat menerangkan variabel tidak bebas

- Ada pengaruh diantara kedua variabel yang diuji

$>$ Apabila $t$ hitung $>t$ tabel, maka Ho ditolak dan Ha diterima, artinya terdapat pengaruh yang nyata antara variabel bebas dengan variabel terikat secara parsial dan sebaliknya.

> Jika t hitung < t tabel, maka Ha ditolak dan Ho diterima, artinya tidak terdapat pengaruh yang nyata secara parsial antara variabel bebas dengan variabel terikat.

\section{c) Uji Koefisien Determinasi $\left(\mathbf{R}^{2}\right)$}

Koefisien determinasi adalah besaran untuk menyatakan tingkat kekuatan pengaruh dalam bentuk persen atau menunjukan seberapa besar persentase variabel terikat $(\mathrm{Y})$ yang dapat dijelaskan oleh variabel bebas $(\mathrm{X})$.

\section{HASIL PENELITIAN \\ Deskripsi Data Penelitian}

Analisis deskripsi data penelitian merupakan suatu analisis yang berkaitan dengan data-data penelitian. Dalam penelitian ini berkaitan dengan kualitas pelayanan akademik $(\mathrm{X})$ dan kepuasan mahasiswa $(\mathrm{Y})$

Penelitian ini menggunakan kuesioner sebagai teknik utama untuk mengumpulkan data. Kuesioner disebar kepada 98 mahasiswa Tahun Akademik 2019/2020 dengan proporsi tertentu pada masing-masing program studi sesuai tabel. Sebelum data terkumpul, terlebih dahulu dilakukan uji coba terhadap 30 mahasiswa di luar sampel penelitian. Uji coba kuesioner dilakukan untuk mengetahui kelemahan kuesioner yang dibuat termasuk berbagai kesulitan yang ada, serta untuk mengetahui tingkat validitas dan realibilitaskuesioner.

Untuk analisis statistik deskriptif, diuraikan paparan tentang distribusi frekwensi dari hasil data yang diperoleh dari para responden terhadap variable-variabel penelitian yang terdiri dari Kualitas Layanan Akademik (sebagai variable bebas) dan kepuasan mahasiswa (sebagai variable terikat)

\section{Kualitas Layanan Akademik}

Pada variabel ini disebar sebanyak 7 kuesioner yang telah dinyatakan valid kepada 98 responden yang diambil dari mahasiswa FKIP Universitas PGRI Palembang yang terpilih sebagai sampel penelitian. Sebagaimana yang terdapat dalam tabel di bawah ini. 
Tabel Kualitas Layanan Akademik

\begin{tabular}{|c|c|c|c|l|c|c|c|c|c|c|}
\hline \multirow{2}{*}{ Kuesioner } & \multicolumn{4}{|c|}{ Kualitas Layanan Akademik } & \multicolumn{4}{|c|}{ Persentase (\%) } \\
\cline { 2 - 11 } & STS & TS & RR & S & SS & STP & TP & CP & P & SP \\
\hline 1 & 0 & 1 & 23 & 42 & 32 & $0 \%$ & $1 \%$ & $23 \%$ & $43 \%$ & $33 \%$ \\
\hline 2 & 0 & 0 & 20 & 44 & 34 & $0 \%$ & $0 \%$ & $20 \%$ & $45 \%$ & $35 \%$ \\
\hline 3 & 0 & 4 & 17 & 50 & 27 & $0 \%$ & $4 \%$ & $17 \%$ & $51 \%$ & $28 \%$ \\
\hline 4 & 0 & 1 & 19 & 52 & 26 & $0 \%$ & $1 \%$ & $19 \%$ & $53 \%$ & $27 \%$ \\
\hline 5 & 0 & 1 & 22 & 49 & 26 & $0 \%$ & $1, \%$ & $22 \%$ & $50 \%$ & $27 \%$ \\
\hline 6 & 0 & 1 & 25 & 49 & 23 & $0 \%$ & $1 \%$ & $26 \%$ & $50 \%$ & $23 \%$ \\
\hline $\mathbf{7}$ & $\mathbf{0}$ & $\mathbf{1}$ & $\mathbf{2 7}$ & $\mathbf{4 7}$ & $\mathbf{2 3}$ & $\mathbf{0} \%$ & $\mathbf{1 \%}$ & $\mathbf{2 8 \%}$ & $\mathbf{4 8 \%}$ & $\mathbf{2 3 \%}$ \\
\hline
\end{tabular}

Sumber : Pengolahan data 2021

Dari tabel di atas hasil sebaran kuesioner kepada responden, dapat dilihat bahawa nilai yang paling tinggi adalah yang menjawab setuju (puas), kemudian dikuti sangat setuju (sangat puas) dan untuk skala sangat tidak setuju (sangat tidak puas) hasilnya nol (tidak ada yang menjawab).

Hal ini dapat dilihat di grafik pada gambar.di bawah ini.

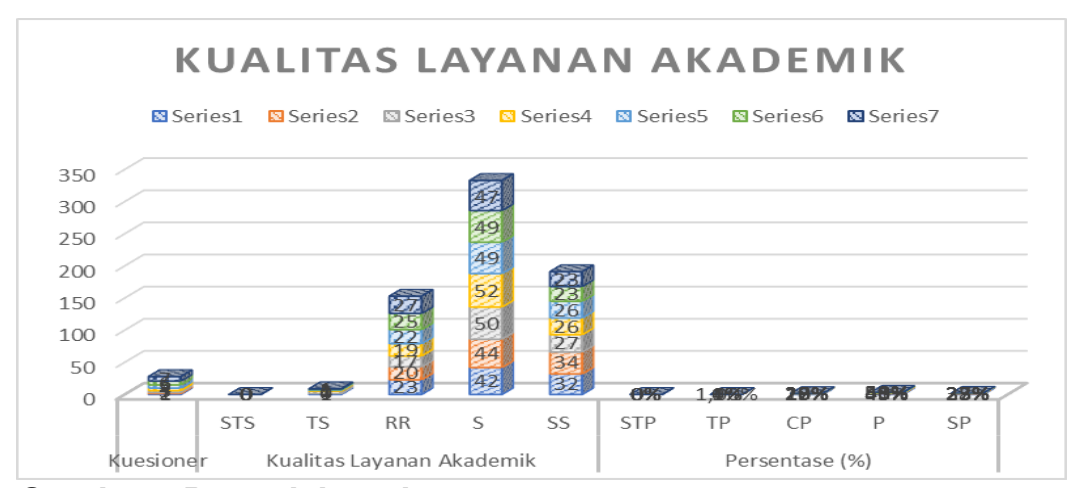

Sumber : Pengolahan data 2021

\section{Kepuasan Mahasiswa}

Pada variabel ini disebar sebanyak 8 kuesioner yang telah dinyatakan valid kepada 98 responden yang diambil dari mahasiswa FKIP Universitas PGRI Palembang. Dan dari hasil penyebaran kuesioner dan setelah dilakukan pengolahan data pada variabel kepuasan mahasiswa didapat hasil sebagaimana yang tertera dalam tabel.

TABEL KEPUASAN MAHASISWA

\begin{tabular}{|c|c|c|c|c|c|c|c|c|c|c|}
\hline \multirow{2}{*}{ Kuesioner } & \multicolumn{4}{|c|}{ Kepuasan Mahasiswa } & \multicolumn{6}{|c|}{ Persentase (\%) } \\
\cline { 2 - 10 } & STS & TS & N & S & SS & STS & TS & N & S & SS \\
\hline 1 & 0 & 0 & 31 & 40 & 27 & $0 \%$ & $0 \%$ & $32 \%$ & $41 \%$ & $28 \%$ \\
\hline 2 & 0 & 0 & 29 & 38 & 31 & $0 \%$ & $0 \%$ & $30 \%$ & $39 \%$ & $32 \%$ \\
\hline 3 & 0 & 1 & 27 & 52 & 24 & $0 \%$ & $1 \%$ & $28 \%$ & $53 \%$ & $24 \%$ \\
\hline 4 & 0 & 0 & 21 & 49 & 28 & $0 \%$ & $0 \%$ & $21 \%$ & $50 \%$ & $29 \%$ \\
\hline 5 & 0 & 0 & 30 & 37 & 31 & $0 \%$ & $0 \%$ & $31 \%$ & $38 \%$ & $32 \%$ \\
\hline 6 & 0 & 0 & 17 & 52 & 29 & $0 \%$ & $0 \%$ & $17 \%$ & $53 \%$ & $30 \%$ \\
\hline 7 & 0 & 0 & 21 & 49 & 28 & $0 \%$ & $0 \%$ & $21 \%$ & $50 \%$ & $29 \%$ \\
\hline 8 & 0 & 0 & 19 & 48 & 31 & $0 \%$ & $0 \%$ & $19 \%$ & $49 \%$ & $32 \%$ \\
\hline
\end{tabular}

Sumber: Pengolahan Data 2021 
Dari tabel di atas hasil sebaran kuesioner kepada responden, dapat dilihat bahawa nilai yang paling tinggi adalah yang menjawab setuju (puas), kemudian dikuti sangat setuju (sangat puas) dan untuk skala sangat tidak setuju (sangat tidak puas) hasilnya nol (tidak ada yang menjawab).

Hal ini dapat dilihat di grafik pada gambar di bawah ini.

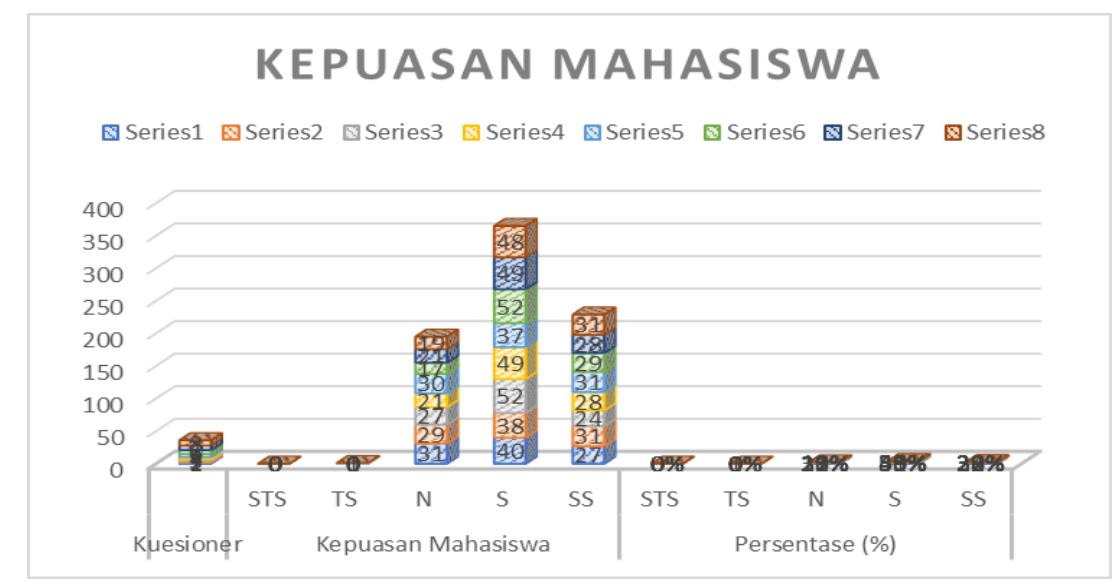

Sumber: Pengolahan data 2021

\section{Analisis Data}

\section{a) Uji Validitas}

Uji validitas digunakan untuk menguji sejauh mana ketepatan alat pengukur dapat mengungkapkan konsep gejala atau kejadian yang diukur. Tabel dibawah ini merupakan bentuk tabulasi hasil pengujian validitas Kualitas Layanan Akademik (X) dengan menggunakan program SPSS versi 25.0. Hasil pengujian validitas untuk variabel Kualitas Layanan Akademik (X) menunjukan bahwa dari 7 item pertanyaan semuanya dinyatakan valid, dengan $r_{\text {hitung }}$ lebih besar dari $r_{\text {tabel. }}$

TABEL VALIDITAS VARIABEL KUALITAS LAYANAN AKADEMIK

\begin{tabular}{|l|l|l|l|l|l|l|l|l|l|}
\hline \multicolumn{2}{|c}{} & $\mathbf{X}_{1}$ & $\mathbf{X}_{2}$ & $\mathbf{X}_{3}$ & $\mathbf{X}_{4}$ & $\mathbf{X}_{5}$ & $\mathbf{X}_{6}$ & $\mathbf{X}_{7}$ & $\mathbf{X}$ \\
\hline \multirow{4}{*}{$\mathrm{X}$} & $\begin{array}{l}\text { Person } \\
\text { Correlation }\end{array}$ & $.611^{* *}$ & $.606^{* *}$ & $.714^{* *}$ & $.521^{* *}$ & $.631^{* *}$ & $.654^{* *}$ & $.563^{* *}$ & 1 \\
\cline { 2 - 11 } & Sig.(2-tailed) & .000 & .000 & .000 & .000 & .000 & .000 & .000 & .000 \\
\cline { 2 - 10 } & $\mathrm{N}$ & 98 & 98 & 98 & 98 & 98 & 98 & 98 & 98 \\
\hline
\end{tabular}

Sumber: Pengolahan Data 2021

Sedangkan hasil pengujian validitas untuk variabel Kepuasan mahasiswa (Y) menunjukan bahwa dari 8 item pertanyaan semuanya dinyatakan valid, dengan $r_{\text {hitung }}$ lebih besar dari $r_{\text {tabel. }}$

TABEL VALIDITAS VARIABEL KEPUASAN MAHASISWA

\begin{tabular}{|l|l|l|l|l|l|l|l|l|l|l|}
\hline \multicolumn{2}{|c|}{} & $\mathbf{X}_{1}$ & $\mathbf{X}_{2}$ & $\mathbf{X}_{3}$ & $\mathbf{X}_{4}$ & $\mathbf{X}_{5}$ & $\mathbf{X}_{6}$ & $\mathbf{X}_{7}$ & $\mathbf{X}_{8}$ & $\mathbf{X}$ \\
\hline \multirow{3}{*}{$\mathrm{Y}$} & Person Correlation & $.654^{* *}$ & $.617^{* *}$ & $.696^{* *}$ & $.653^{* *}$ & $.690^{* *}$ & $.654^{* *}$ & $.627^{* *}$ & $.724^{* *}$ & 1 \\
\cline { 2 - 11 } & Sig.(2-tailed) & .000 & .000 & .000 & .000 & .000 & .000 & .000 & .000 & .000 \\
\cline { 2 - 11 } & $\mathrm{N}$ & 98 & 98 & 98 & 98 & 98 & 98 & 98 & 98 & 98 \\
\hline
\end{tabular}

\section{b) Uji Reliabilitas}

Pengujian reliabilitas yang digunakan untuk menunjukkan sejauh mana suatu alat pengukur dapat dipercaya atau dapat diandalkan. Pengujian dan pencarian nilai 
reliabilitas menggunakan program SPSS versi 25, dengan metode alphacronbach. Adapun penyederhanaan bentuk tabulasi hasil uji reliabilitas variabel Kualitas Layanan Akademik (X) dan variabel Kepuasan Mahasiswa (Y) diperlihatkan pada tabel berikut.

\section{Tabel Reliabilitas Variabel Kualitas Layanan Akademik Reliability Statistics}

\begin{tabular}{|l|l|}
\hline Cronbach's Alpha & N ofltems \\
\hline .726 & 7 \\
\hline
\end{tabular}

Dari table di atas dapat dilihat bahwa hasil uji reliabilitas variable Kualitas Layanan Akademik (X) yang terdiri dari 7 item pertanyaan dengan tingkat signifikan $5 \%$ mempunyai nilai 0.726 , lalu nilai tersebut dibandingkan dengan nilair ${ }_{\text {tabel }}$ dengan $\mathrm{N}=98$ dan diperoleh nilai $r_{\text {tabel }}$ sebesar 0.1654 . Dari perbandingan nilai ini berartir

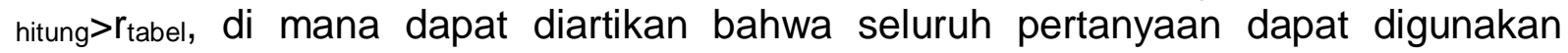
sebagai intrumen penelitian.

\section{Tabel Reliabilitas Variabel Kepuasan Mahasiswa Reliability Statistic

\begin{tabular}{|c|c|}
\hline Cronbach's Alpha & N ofltems \\
\hline .818 & 8 \\
\hline
\end{tabular}

Dan pada tabel diatas menunjukan bahwa dari hasil uji reliabilitas pada variable kepuasan mahasiswa untuk 8 item pertanyaan dengan tingkat signifikan 5\% mempunyai nilai 0.818 , lalu nilai tersebut dibandingkan dengan nilai $r_{\text {tabel }}$ dengan $\mathrm{N}=98$ dan diperoleh nilai $r_{\text {tabel }}$ sebesar 0.1654 . Dari perbandingan nilai ini berarti $r_{\text {hitung }}>r_{\text {table, }}$ di mana dapat diartikan bahwa seluruh pertanyaan dapat digunakan sebagai intrumen penelitian.

\section{c) Analisis Regresi Linear Sederhana}

Analisis regresi linier sederhana digunakan untuk mengetahui pengaruh antara dua variabel yang diteliti. Adapun hasil pengukuran arah hubungan antara variabel KualitasLayananAkademik (X) dan variabelKepuasanMahasiswa(Y) diperlihatkan pada tabel berikut ini :

\section{Coefficients $^{\mathrm{a}}$}

\section{TABEL OUTPUT COEFFICIENTS X TERHADAP Y}

\begin{tabular}{|c|c|c|c|c|c|}
\hline \multirow[t]{2}{*}{ Model } & \multicolumn{2}{|c|}{$\begin{array}{c}\text { Unstandardized } \\
\text { Coefficients }\end{array}$} & \multirow{2}{*}{\begin{tabular}{c|}
$\begin{array}{c}\text { Standardized } \\
\text { Coefficients }\end{array}$ \\
Beta \\
\end{tabular}} & \multirow[b]{2}{*}{$t$} & \multirow[b]{2}{*}{ Sig. } \\
\hline & B & Std. Error & & & \\
\hline $\begin{array}{l}\text { (Constant) } \\
\mathrm{KLA}\end{array}$ & $\begin{array}{r}16.327 \\
.569\end{array}$ & $\begin{array}{r}3.104 \\
.109\end{array}$ & .469 & $\begin{array}{l}5.260 \\
5.207\end{array}$ & $\begin{array}{l}.000 \\
.000\end{array}$ \\
\hline
\end{tabular}

a. DependentVariable: Kepuasan Mahasiswa (Y)

Dari tabel di atas menunjukkan bahwa koefisien konstanta "a" bernilai 16.327 dan koefisien regresi "b" bernilai 0,569. Rumusan regresi linier $Y=16.327+0,569 X$, dapat diartikan bahwa: 
1. Koefisien konstanta merupakan nilai tetap, artinya jika tidak ada pengaruh variabel Kualitas Layanan Akademik, maka kepuasan mahasiswa bernilai 16.327.

2. Koefisien variabel merupakan nilai yang mempengaruhi (pengubah), artinya bahwa bila terjadi penambahan nilai pada variabel Kualitas Layanan Akademik, maka kepuasan mahasiswa akan meningkat sebesar 0,569.

\section{d) Uji Hipotesis}

Uji hipotesis pada penelitian ini menggunakan uji-t, bertujuan untuk menguji signifikansi hubungan antara variabel $\mathrm{X}$ dan $\mathrm{Y}$, apakah variabel $\mathrm{X}$ (Kualitas Layanan Akademik) benar-benar berpengaruh terhadap variabel $Y$ (Kepuasan Mahasiswa). Adapun hipotesis yang digunakan adalah:

Ho : Tidak ada pengaruh signifikan antara Kualitas Layanan Akademik terhadap Kepuasan Mahasiswa FKIP Universitas PGRI Palembang.

$\mathrm{Ha}$ : Ada pengaruh signifikan antara Kualitas Layanan Akademik terhadap Kepuasan Mahasiswa FKIP Universitas PGRI Palembang.

Sebagaimana diperlihatkan pada tabel diatas nilai untuk thitung adalah 5.207. Sedangkan berdasarkan tabel data untuk uji-t dengan sampel berjumlah 98 didapatkan nilai $t_{\text {tabel }}$ adalah 1,660. Dengan demikian perbandingan antara thitung dan $t_{\text {tabel }}$ dinyatakan bahwa thitung $(5.207)>t_{\text {tabel }}(1,660)$. Maka kriteria pengujian hipotesis yang berlaku adalah Ho ditolak dan $\mathrm{Ha}$ diterima, dan hipotesis penelitian menyatakan bahwa ada pengaruh signifikan antara Kualitas Layanan Akademik terhadap Kepuasan Mahasiswa FKIP Universitas PGRI Palembang.

\section{E. KESIMPULAN}

1. Terdapat pengaruh yang signifikan antara kualitas layanan akademik di Pusat PelayananTerpadu Universitas PGRI Palembang terhadap kepuasan mahasiswa FKIP Universitas PGRI Palembang Tahun Akademik 2019-2020 sebesar $56,9 \%$ dalam artian pelayanan memberi pengaruh kepuasan mahasiswa sebesar $56,9 \%$ dan sisanya dipengaruhi oleh faktor lain dalam artian kepuasan mahasiswa dipengaruhi oleh faktor lain.

2. Dengan melihat hasil dari penelitian maka kualitas layanan di Universitas PGRI Palembang masih perlu ditingkatkan diantaranya meliputi: tampilan fisik (tangibles), kehandalan (reliability), kesigapan (responsiveness), jaminan (assurance), dan empati (empathy). Dalam penelitian diketahui kualitas layanan akademik menunjukan hasil yang cukup baik $(56,9 \%)$, hal ini tentunya untuk dapat menjadi perhatian bagi seluruh civitas akademik Universitas PGRI Palembang untuk meningkatkan layanannya kepada mahasiswa agar menjadi baik. Karena hal ini sangat penting dalam menimbulkan rasa kepuasan mahasiswa terhadap kualitas layanan akademik. Apabila ada harapan dan keinginan mahasiswa dibidang pelayanan tidak sesuai dengan kenyataan yang mereka peroleh maka mahasiswa akan merasa tidak puas. Sebaliknya Apabila harapan dan keinginan mahasiswa dibidang pelayanan sesuai dengan kenyataan yang mereka peroleh maka mahasiswa akan merasa puas dan ini akan membawa dampak positip bagi Universitas PGRI Palembang. 


\section{DAFTAR PUSTAKA}

Maheswari, Hesti. 2013. Analisis Perbandingan Kepuasan Mahasiswa terhadap Kualitas Proses Belajar Mengajar Dosen Tetap dengan Dosen Tidak Tetap pada Universitas Mercu Buana. Jurnal SWOT. Vol.6 No.1 Februari 2013.

Paly, Basir. 2014. Tingkat Kepuasan Mahasiswa terhadap Kinerja Proses Belajar Mengajar (PBM) Dosen. Jurnal Al Hikmah. Vol.XV Nomor 2/2014.

Rahayu, Dwi. 2013. Pengaruh Service Qualityterhadap Tingkat Kepuasan MahasiswaAkuntansi Fakultas Ekonomi Universitas Maritim Raja Ali Haji Tanjung Pinang. Jurnal UMRAH.

Sugiyono. 2017. Metode Penelitian Pendidikan Pendekatan Kuantitatif, Kualitatif dan $R \& D$. Bandung: Alfabetha.

Tjiptono F dan Gregorius Chandra. 2014). Manajemen Kualitas Jasa. Yogyakarta: Penerbit Andi.

Tuerah, Febriany Feibe Rosaline, dkk. 2015. Analisis Kualitas Layanan Akademik Dan Administrasi terhadap Kepuasan Mahasiswa. Jurnal EMBA 422.Vol. 3 No.4 Desember 2015 ISSN 2303-1174.

UU No. 20 Tahun 2003 tentang Sistem Pendidikan Nasional 